\title{
MODERNISASI STRATEGI UMKM DEMI RESISTENSI USAHA DI MASA PANDEMI COVID-19
}

\author{
Anandita Zulia Putri ${ }^{1)}$, Ningrum Pramudiati ${ }^{2}$, Lulu Amalia Nusron ${ }^{3)}$, Deden Prasetyo ${ }^{4)}$ \\ 1) Program Sarjana Akuntansi, Fakultas Bisnis, Universitas PGRI Yogyakarta, e-mail: anandita.zp@upy.ac.id \\ 2) Program Sarjana Akuntansi, Fakultas Bisnis, Universitas PGRI Yogyakarta, e-mail: \\ pramudiati.ningrum@upy.ac.id \\ 3) Program Sarjana Akuntansi, Fakultas Bisnis, Universitas PGRI Yogyakarta, email: lulu.amalia@upy.ac.id \\ 4) Program Sarjana Akuntansi, Fakultas Bisnis, Universitas PGRI Yogyakarta, e-mail: dedenprasetyo15@ gmail.com
}

\begin{abstract}
Abstrak
Perkembangan Usaha Mikro Kecil Menengah di Indonesia saat ini memiliki perkembangan yang sangat pesat. Terlebih lagi dengan adanya perkembangan teknologi maka akan membawa angin segar bagi UMKM dalam meningkatkan eksistensinya di masyarakat. Tujuan pelaksanaan kegiatan ini adalah untuk membantu UMKM Al Barik yang terdapat di desa Sidomulyo Kabupaten Bantul dalam menjalankan usahanya di masa pendemi Covid-19 serta menghadapi perkembangan teknologi. Tim pengabdi lakukan berbagaii strategi untuk mendorong UMKM agar bisa melalui masa sulit selama pandemi Covid-19. Program kerja yang kelompok pengabdi lakukan antara lain adalah membantu UMKM dalam membuat profil dan visi misi, membantu modal awal, pembukuan, pemasaran melalui e-commerce, foto dan video produk, desain kemasan, dan pengelolaan akun usaha. Kegiatan yang tim pengabdi lakukan selama pengabdian berhasil terlaksana dan sukses. Hasil ini dapat dilihat adanya peningkatan penjualan online dari market place, peningkatan keterampilan dalam pembukuan, serta kemampuan dalam melakukan branding produk.
\end{abstract}

Kata Kunci: Covid-19, UMKM, Strategi, Modern

\begin{abstract}
Micro, Small, and Medium Enterprises (MSMEs) in Indonesia are currently developing very rapidly. Moreover, the development of technology brings fresh air for MSMEs in increasing their existence in society. The work plan that we are carrying out is a strategy to encourage MSMEs to go through difficult times during the Covid-19 pandemic. The purpose of implementing this activity is to help "Al Barik MSME" in Sidomulyo Village Bantul district Yogyakarta in carrying out their business during the Covid-19 pandemic and responding to technological developments. Our work programs include assisting Al Barik MSME in creating the business profile these are vision and mission, assisting initial capital, bookkeeping, marketing through e-commerce, product photos and videos, packaging design, managing business accounts, and improving signboard. Our service activities were carried out well and successfully. These results can be seen in an increase in online sales from the marketplace, increased skills in bookkeeping, and the ability to do product branding.
\end{abstract}

Keywords: Covid-19, SMEs, Strategic, Modern

\section{PENDAHULUAN}

Perkembangan Usaha Mikro Kecil Menengah (UMKM) di Indonesia pada saat ini dianggap memiliki perkembangan yang sangat pesat. Sektor
UMKM ini merupakan sektor yang sangat diperhatikan oleh pemerintah, hal ini ditunjukkan dengan perhatian pemerintah pada sektor UMKM sangat besar. Menurut Sugiarti et al., (2019) UMKM memiliki peran besar dalam pembangunan ekonomi di Indonesia, pertumbuhan ekonomi, serta membuka 
lapangan kerja baru. Saat ini UMKM di Indonesia memiliki perkembangan dan telah terbagi dalam berbagai sektor. Perkembangan UMKM yang pesat diharapkan mampu meningkatkan pertumbuhan ekonomi dengan menyerap pendapatan daerah, dan mampu menekan angka pengganguran dengan dibukanya lapangan kerja baru. Terlebih lagi dengan bergabungnya Indonesia dalam Masyarakat Ekonomi Asia (MEA) maka diharapkan pelaku UMKM dapat bersaing di pasar bebas dengan produk-produk kreatifnya, di sisi lain juga akan meningkatkan ekspor di Indonesia.

UMKM Al Barik merupakan salah satu UMKM yang terkena dampak Covid-19 yang beralamat di Dukuh Widaran, Ponggok, Sidomulyo, Bambanglipuro, Bantul. UMKM Al Barik didirikan oleh Ibu Sri Purwanti dan rekan-rekan pada 10 januari 2008 memproduksi keripik yang berbahan baku bonggol pisang, buah pisang, kulit pisang, batang pisang, cabe, pare, dan jamur. UMKM ini memiliki 4 karyawan yang bergerak dalam bidang produksi. Kisaran harga produk yang ditawarkan oleh keripik Al Barik sangat terjangkau. UMKM ini mengolah produk dengan bahan baku pohon pisang, mulai dari bonggol sampai buah pisang. Buah pisang adalah salah satu contoh bahan pangan yang dapat diolah menjadi berbagai macam produk makanan, meski tanpa diolah buah ini bisa langsung dikonsumsi dan memiliki rasa yang enak (Angelina et al., 2020). Salah satu olahan yang buat oleh UMKM ini yaitu keripik bonggol pisang. Ciri khas dari UMKM Al Barik ialah penggunaan bonggol pisang sebagai bahan baku keripik. Keripik bonggol pisang ini berbeda dari yang lain karena memanfaatkan bonggol pisang menjadi makanan ringan yang biasanya masyarakat hanya menggunakan bonggol pisang untuk pakan ternak. Kualitas dari produk yang dihasilkan juga mengandung manfaat bagi kesehatan salah satunya yaitu mencegah asam lambung.

Perkembangan UMKM di Indonesia juga dibarengi dengan pesatnya perkembangan ilmu pengetahuan dan teknologi di Indonesia. Perkembangan ilmu pengetahuan dan teknologi telah memengaruhi pola perilaku manusia dalam mengakses beragam informasi dan berbagai fitur layanan elektronik. Menurut Utari \& Dewi, (2014) perkembangan teknologi dapat meningkatkan produksi dengan pemanfaatan teknologi yang modern sehingga pendapatan UMKM yang diterima juga akan semakin meningkat. Hal ini tentunya akan menjadi angin segar bagi para pelaku UMKM di tengah pendemi covid-19 dimana dengan digalakkannya himbauan social distancing oleh pemerintah menjadikan teknologi sebagai pangsa pasar utama bagi para pelaku UMKM. Disisi lain teknologi juga menjadi permasalahan bagi para pelaku UMKM. Berdasarkan hasil survei tim pengabdi di UMKM Al Barik terdapat beberapa temuan masalah yang sebagian berkaitan dengan teknologi dan modernisasi. Temuan masalah yang didapatkan antara lain pemasaran yang belum menggunakan teknologi dengan baik, pencatatan keuangan masih masih manual, kemasan produk yang belum menyesuaikan dengan perkembangan zaman dan pemanfaatan sosial media sebagai sarana promosi belum dilakukan dengan maksimal.

Penelitian yang dilakukan Helmalia \& Afrinawati, (2018) tentang pengaruh e-commerce terhadap penjualan UMKM menunjukkan hasil positif. Maka dari itu demi meningkatkan pendapatan UMKM perlu melakukan penjualan melalui $e$ commerce. UMKM Al Barik belum bisa memanfaatkan penggunaan e-commerce sebagai sarana penjualan sehingga memengaruhi pendapatan UMKM terlebih lagi pada masa pendemi. Selain itu, kemasan produk yang menarik dan mengikuti zaman tentunya dapat menarik perhatian konsumen dan meningkatkan pendapatan, hal ini didukung pada penelitian Apriyanti (2018) yang menjelaskan bahwa tampilan pada kemasan produk dapat menarik konsumen dan meningkatkan pendapatan. Kemasan produk Al Barik memiliki tampilan yang kurang menarik sehingga kurang dalam mendapatkan perhatian konsumen.

Pemanfaatan sosial media sebagai sarana promosi merupakan salah satu solusi dalam meningkatkan pendapatan. Penelitian Purwidiantoro et al., (2016) menyatakan bahwa media sosial dapat meningkatkan penjualan hingga lebih dari $100 \%$ apabila perusahaann melakukan update informasi secara konsisten melalui media sosial setiap hari. 
Pengelolaan akun media sosial pada UMKM Al Barik belum dilakukan secara efektif, sehingga berpengaruh terhadap penjualan yang dilakukan. Sebelum adanya Covid-19 penjualan dilakukan secara langsung dengan menitipkan di pusat oleholeh, namun karena adanya Covid-19 penjualan secara langsung sulit untuk dilakukan sehingga harus mengubah ke srategi penjualan yang baru yaitu melalui media online.

\section{METODOLOGI PENGABDIAN}

Pelaksanaan kegiatan pengabdian masyarakat di UMKM Al Barik dilakukan secara luring dan daring selama 4 bulan. Pelaksanaan kegiatan dilakukan dari bulan September-Desember 2020. Adapun tahapan dan metode pelaksanaan kegiatan yang dilakukan adalah sebagai berikut:

\section{Tahap Persiapan}

Persiapan dilakukan dengan melakukan survei lokasi dan pendalaman masalah yang dilakukan dengan observasi dan wawancara. Pengabdi bertemu langsung dengan pemilik UMKM dan menemukan permasalahan. Kemudian pengabdi mendiskusikan solusi untuk permasalahan yang dialami UMKM. Selanjutnya, pengabdi mengkoordinasikan usulan solusi kepada pihak UMKM dan membuat perencanaan pelaksanaan kegiatan.

\section{Tahap Pelaksanaan.}

Tahap pelaksanaan yang dilakukan pengabdi melalui beberapa metode yakni:

\section{a. Sosialisasi Pentingnya Visi Misi UMKM}

Kegiatan ini bertujuan untuk menentukan tujuan perusahaan. UMKM yang memiliki visi dan misi berarti sama saja dengan memetakan secara jelas, apa saja yang menjadi dasar tujuan didirikannya sebuah usaha. Hal inilah yang selanjutnya diharapkan oleh sebuah UMKM akan memberikan dampak yang signifikan pada peningkatan keuntungan dan kemajuan UMKM. Kegiatan dilakukan secara luring hingga mencapai kesepakatan terciptanya visi dan misi sesuai dengan keinginan pemilik.

\section{b. Pemberian Modal Kepada Pemilik}

UMKM Al Barik sempat berhenti beroperasi dimasa pandemic covid-19 karena pemilik terkendala keterbatasan modal sehingga tim pengabdi membantu memberikan modal awal untuk memulai kembali usaha ini. Pengabdi berdiskusi dan menentukan jumlah modal awal dilanjutkan dengan memberikan langsung kepada ketua UMKM. Pengabdi berharap dengan adanya tambahan modal awal, maka UMKM dapat berjalan seperti sedia kala.

\section{c. Pendampingan Pembukuan Sederhana}

Program kerja pembukuan sederhana diajukan karena UMKM belum memiliki pembukuan usaha dengan mencatat segala transaksi keuangan yang ada. Kegiatan ini bertujuan untuk memperdalam pengetahuan mengenai pembukuan dan melatih karyawan agar dapat mengaplikasikannya. Pendampingan dilakukan pada setiap proses akuntansi. Menurut Jusup (2001), proses akuntansi meliputi; pencatatan, penggolongan, peringkasan, pelaporan dan penganalisa data keuangan. Dalam kegiatan ini pengabdi melakukan pendampingan secara luring dengan memberikan modul pembukuan sederhana.

\section{d. Pendampingan Pemasaran Digital}

Digital marketing adalah kegiatan promosi dan pencarian pasar melalui media digital secara online dengan memanfaatkan berbagai sarana misalnya jejaring sosial (Puspitasari dkk, 2019). Produk digital marketing yang dibangun sebagai strategi pemasaran keripik bonggol pisang dari UMKM Al Barik ini ialah sosial media yang terintegrasi dengan $e$ commerce dan aplikasi marketplace. Kegiatan ini bertujuan untuk memudahkan UMKM memantau dan menyediakan segala kebutuhan dan keinginan calon konsumen. Konsumen bisa lebih mudah membeli berdasarkan kebutuhan tanpa ada batasan geografis dan waktu.

\section{e. Pendampingan Penjualan Online}

Setelah memasarkan produk digital yang telah dibentuk oleh pengabdi, maka pengabdi perlu mendampingi UMKM Al Barik ketika sedang 
menjual dan menerima pesanan produk secara online. Kegiatan ini diharapkan dapat meningkatkan penjualan produk yang sempat berhenti sebelumnya. Adapun penjualan produk dilakukan pada aplikasi instagram dan shopee.

\section{f. Strategi Branding Produk}

Brand adalah sebuah nama, istilah, tanda, symbol, rancangan atau kombinasi semua unsur yang digunakan untuk mengenali produk atau jasa dari seseorang atau sebuah kelompok penjual dari pesaingnya (Philip, 2000). Brand berfungsi sebagai satu ikatan yang kuat secara emosional antara pelanggan dan konsumen, tataran bagi opsi-opsi strategis dan kekuatan yang mempengaruhi financial. Branding sangat penting dalam memasarkan produk. Pengabdi membuat desain baru pada kemasan agar terlihat menarik. Selain itu, pengabdi juga melakukan foto dan video produk untuk disebarluaskan pada sosial media dan aplikasi marketplace yang telah pengabdi bentuk sebelumnya.

\section{Tahap Evaluasi Kegiatan}

Tahap ini dilakukan pada akhir pengabdian untuk mengevaluasi apakah capaian kegiatan pengabdian ini dapat terpenuhi. Evaluasi dilakukan melalui wawancara kepada Anggota UMKM Al Barik yang merupakan peserta kegiatan ini.

\section{PELAKSANAAN KEGIATAN}

\section{Tahap Persiapan}

Pada tahap persiapan ini, pengabdi melakukan koordinasi tim dengan pihak UMKM. Setelah pengabdi mendapatkan izin untuk melaksanakan pengabdian pada UMKM Al Barik, pengabdi melakukan observasi untuk mendapatkan informasi dan mengidentifikasi masalah yang terjadi dalam UMKM tersebut. Pengabdi melakukan wawancara pada ketua dan anggota UMKM Al Barik pada tanggal 19 September 2020. Hasil wawancara menunjukkan kendala atau permasalahan yang sedang dihadapi antara lain yaitu; UMKM belum memiliki visi misi perusahaan dan pembukuan atau pencatatan transaksi keuangan. Pemasaran produk juga belum dilakukan secara optimal. Selain itu, kemasan produk juga masih terbilang sangat sederhana. Terlebih usaha ini harus terhenti karena adanya pandemi Covid-19 yang menyebabkan penjualan menurun dan UMKMK Al Barik kehabisan modal.

Langkah kedua, pengabdi melakukan koordinasi tim untuk menentukan solusi atas permasalahan yang dialami UMKM untuk diusulkan kepada UMKM. Pengabdi menyusun program kerja untuk disampaikan kepada pemilik UMKM pada tanggal 10 Oktober 2020. Adapun program kerja yang pengabdi susun sebagai solusi dari permasalahan yang ada diantaranya sosialisasi pentingnya visi misi, pemberian modal kepada pemilik, pendampingan pembukuan sederhana, pendampingan digital marketing, pendampingan penjualan online, dan melakukan strategi branding produk.

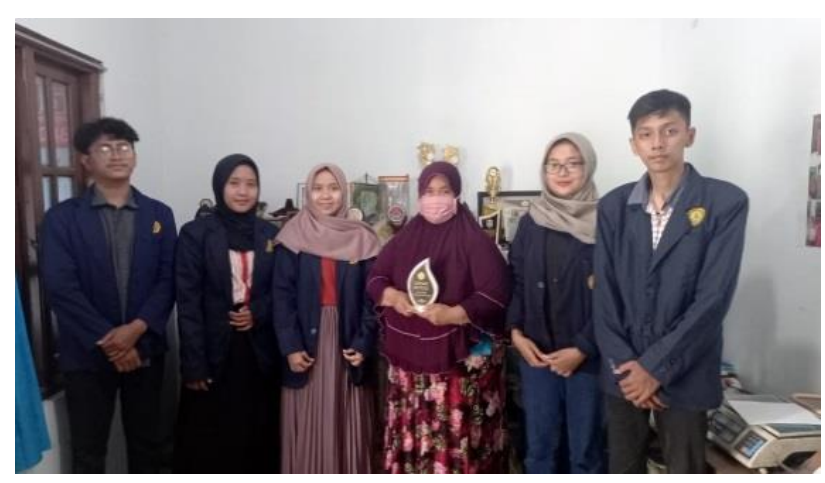

Gambar 1. Dokumentasi Kegiatan Survei dengan Pemilik UMKM

\section{Tahap Pelaksanaan}

\section{a. Sosialisasi Pentingnya Visi Misi UMKM}

UMKM Al Barik belum memiliki pernyataan tertulis mengenai visi, misi dan tujuan usaha. Namun secara umum hal tersebut telah ada secara tersirat dalam wawancara dengan ketua usaha UMKM Al Barik ketika pengabdi melakukan observasi. UMKM Al Barik harus memiliki arahan yang jelas dalam menjalankan usahanya untuk dapat bersaing dalam industri. Arah usaha tercermin dalam visi, misi, dan tujuan yang dimiliki UMKM Al Barik. Kegiatan pembentukan visi misi ini dilakukan secara luring dan berdiskusi langsung dengan pemilik UMKM. Visi menunjukkan keadaan masa depan suatu organisasi yang mungkin terjadi dan diinginkan. Visi menjelaskan impian yang ingin direalisasikan oleh 
suatu lembaga organisasi di dalam waktu tertentu. Misi menjelaskan alasan atau tujuan suatu lembaga organisasi didirikan, sedangkan tujuan merupakan hasil akhir yang berusaha untuk dicapai oleh organisasi untuk mewujudkan misinya dalam jangka waktu tertentu.

\section{b. Pendampingan Pembukuan Sederhana}

UMKM Al Barik belum melakukan pembukuan atau pencatatan setiap transaksi pembelian bahan baku, produksi, sampai dengan penjualan. Pemilik hanya menghitung berapa banyak uang yang masuk pada hari itu untuk dijadikan modal lagi keesokan harinya. Kegiatan operasional UMKM cukup banyak mulai dari pembelian bahan baku, penggajian karyawan, penjualan produk, dan lain lain. Menurut tim pengabdi sangatlah penting untuk mencatat setiap transaksi agar pemilik bisa menghitung keuntungan yang didapat setiap hari atau bulannya. Pengabdi mendampingi ketua dan anggota UMKM bagian keuangan atau kasir untuk mencatat transaksi secara manual menggunakan buku pembantu yang berisi rincian transaksi, debit (uang masuk), kredit (uang keluar), dan saldo akhir. Pencatatan transaksi disesuaikan dengan nota yang ada setiap harinya. Kegiatan pendampingan ini dilaksanakan secara daring dan luring setiap minggu selama 2 bulan sejak tanggal 10 Oktober 2020 sampai dengan tanggal 5 Desember 2020.

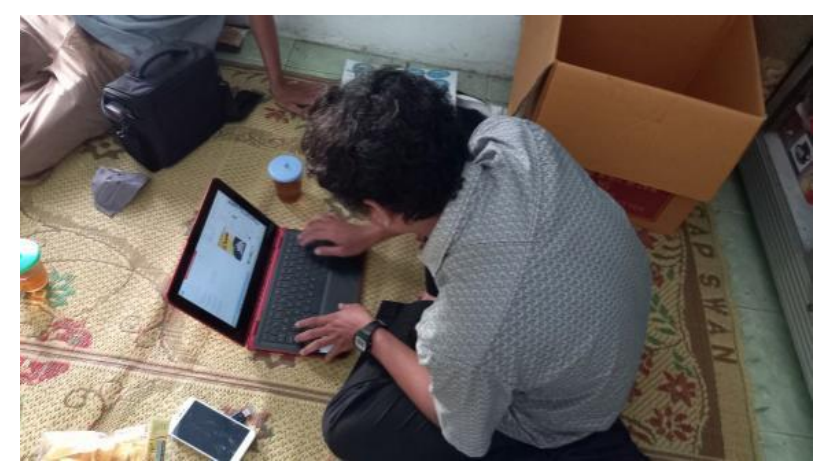

Gambar 3. Pendampingan pembukuan dengan komputer

\section{c. Pendampingan Pemasaran Digital}

Pendampingan pemasaran digital dilaksankan secara daring dan luring pada tanggal 21 November 2020 sampai dengan 10 Desember 2020. Dalam kegiatan ini, pengabdi merubah tampilan akun sosial media di Instagram dan melakukan pembaruan feed dengan mengupload foto dan video agar tampak rapi dan menarik. Selain itu, pengabdi juga membuatkan akun market place yaitu Shopee untuk membantu penjualan.
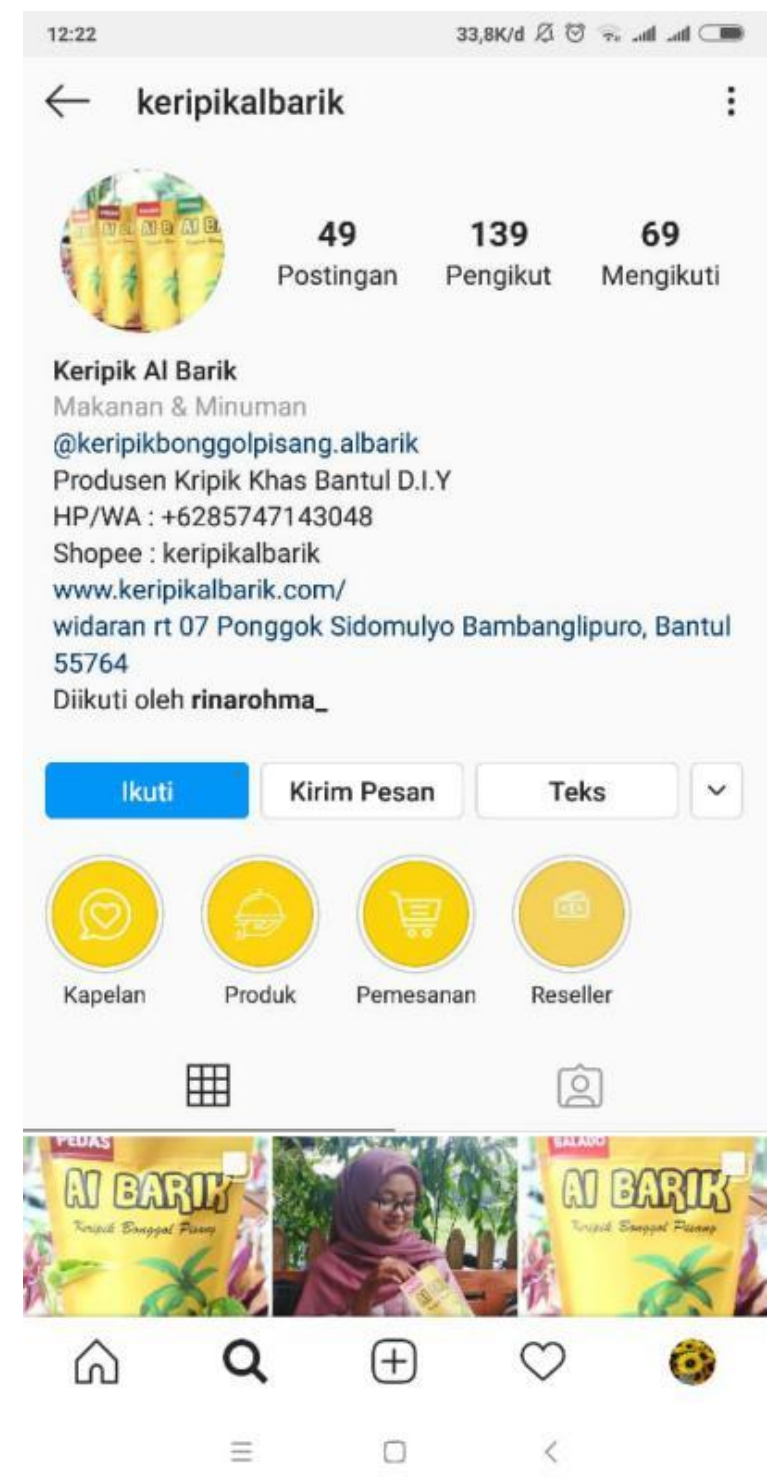

Gambar 4. Setelah dilakukan pembaruan feed di Instagram

\section{d. Pendampingan Penjualan Online}

Kegiatan pendampingan penjualan online, tim pengabdi menjelaskan kepada ketua dan kelompok UMKM bahwa penjualan tidak hanya dilakukan door to door atau offline saja, melainkan juga dapat dilakukan secara door to door namun dilakukan secara online juga. Penjualan online pada saat ini sedang sangat berkembang dengan meningkatnya 
teknologi dan dampak pandemi Covid 19 yang membuat masyarakat cenderung melakukan perbelanjaan secara online. Oleh sebab itu, pengabdi memanfaatkan peluang ini dengan membuatkan akun Shopee dan Instagram sebagai media pemasaran dan penjualan secara online. Kegiatan ini dilakukan secara daring dan luring dari tanggal 1 Desember 2020 sampai dengan 21 Desember 2020.

\section{Strategi Branding Produk}

Kegiatan ini dilakukan kepada seluruh anggota UMKM untuk saling berbagi ide membuat branding produk. Pengabdi memberikan arahan cara melakukan foto dan video produk agar terlihat menarik. Pengabdi juga membuatkan desain logo dan kemasan produk. Kegiatan ini dilakukan sebanyak 3 kali pertemuan pada tanggal 28 November 2020 sampai 12 Desember 2020.

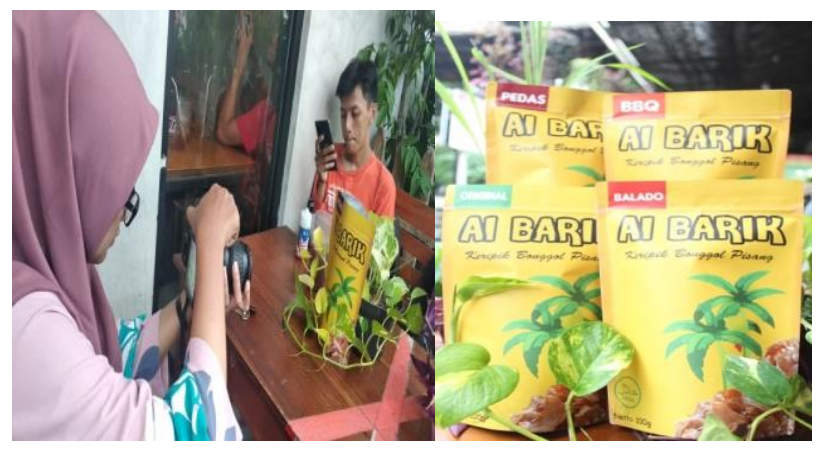

Gambar 5. Pembuatan branding produk dalam kemasan

\section{Tahap Evaluasi Kegiatan}

Tahap ini dilakukan pada akhir pengabdian untuk mengevaluasi apakah capaian kegiatan pengabdian ini telah terpenuhi. Evaluasi dilakukan melalui wawancara kepada ketua serta anggota yang merupakan peserta kegiatan ini. Setelah dilakukan evaluasi, pengabdi akan tetap memantau perkembangan dan keberlanjutan program kerja yang sudah dijalankan agar terlaksana secara maksimal.

\section{HASIL DAN PEMBAHASAN}

Hasil dari kegiatan pengabdian yang dilakukan pada UMKM Al Barik yang dilakukan dari bulan September sampai Desember yakni sebagai berikut:

\section{Sosialisasi Pentingnya Visi Misi UMKM}

Kegiatan ini berlangsung sebanyak satu kali pertemuan yang dilakukan pada tanggal 19 September 2020 secara luring. Pengabdi telah menjelaskan kepada pemilik UMKM bahwa visi, misi, tujuan suatu usaha sangatlah penting. UMKM Al Barik harus memiliki arahan yang jelas dalam menjalankan usahanya untuk dapat bersaing dalam industri. Arah usaha keripik tercermin dalam visi, misi, dan tujuan yang dimiliki UMKM Al Barik. Pada dasarnya, visi, misi, dan tujuan perusahaan sudah tersirat dalam wawancara antara pengabdi dan pemilik UMKM. Dalam kegiatan ini, pemilik UMKM dan pengabdi berdiskusi untuk menentukan visi, misi, dan tujuan usaha. Berdasarkan hasil diskusi dengan pemilik UMKM, maka terbentuklah visi usaha keripik bonggol pisang $\mathrm{Al}$ Barik yaitu usaha yang mampu menghasilkan produk keripik yang berkualitas. Hal ini merupakan hal yang selalu diperhatikan oleh pemilik usaha keripik Al Barik dalam setiap proses produksi.

Misi usaha keripik ini adalah untuk memperkenalkan keripik sebagai salah satu makanan ringan yang sehat bagi masyarakat. Sedangkan tujuan usaha keripik yaitu mampu meningkatkan taraf kemakmuran kehidupan para anggotanya serta mampu menyerap tenaga kerja dari lingkungan sekitar sehingga meningkatkan penghasilan masyarakat sekitar yang pada umumnya bekerja sebagai buruh bangunan. Produk keripik yang dipasarkan oleh usaha kecil ini merupakan produk yang berasal dari alam dan tidak ditambahkan dengan bahan-bahan yang berbahaya bagi kesehatan masyarakat seperti pengawet, sehingga aman untuk dikonsumsi. Walaupun, hingga saat ini usaha ini belum mendapatkan standar kesehatan dari Departemen Kesehatan karena masih dalam proses pengajuan.

\section{Pemberian Modal Kepada Pemilik}

Kegiatan ini berlangsung 1 kali pertemuan luring pada tanggal 5 Oktober 2020. Selama masa pandemi, modal yang dimiliki oleh UMKM Al Barik tidak dapat diputarkan sehingga kekurangan modal. Pengabdi memberikan modal tambahan agar UMKM 
Al Barik bisa memulai kembali proses produksi keripik tersebut.

\section{Pendampingan Pembukuan Sederhana}

Kegiatan ini berlangsung sebanyak 3 kali dengan durasi 2-3 jam setiap pertemuan. Peserta yang hadir yakni para anggota UMKM Al Barik. Selama ini, seluruh transaksi baik pemasukan maupun pengeluaran belum dicatat dengan baik. Hal ini menyebabkan UMKM tidak dapat mengetahui informasi keuangan baik dari hasil penjualan, biaya yang dikeluarkan, dan keuntungan usahanya. Seluruh karyawan yang ada hanya diberikan tanggung jawab masing-masing dalam hal produksi. Pengabdi menyarankan kepada ketua untuk menunjuk salah satu anggota untuk mencatat setiap transaksi dan membentuk prosedur yang jelas agar ada dual control dalam usaha. Dalam kegiatan ini pengabdi melalui pemateri kegiatan, memberikan pengetahuan terkait pencatatan transaksi keuangan atau pembukuan sederhana secara manual. Pendampingan pembukuan yakni dengan rincian sebagai berikut:

a. Pembaharuan daftar harga beli dan harga jual produk

b. Membuat jurnal penerimaan kas

c. Membuat jurnal pengeluaran kas

d. Membuat jurnal penjualan

e. Membuat jurnal pembelian

f. Membuat buku besar dan neraca saldo

g. Membuat laporan keuangan

\section{Pendampingan Pemasaran Digital}

Dalam kegiatan ini, pengabdi memberikan arahan kepada ketua dan anggota untuk memasarkan produk secara digital. Salah satu caranya adalah mengambil gambar produk dan video pemasaran untuk dibagikan kepada calon konsumen melalui Status Whatsapp, Story Instagram, Feed Instagram, dan Shopee. Kegiatan ini dilakukan daring dan luring pada tanggal 21 November 2020 sampai dengan 10 Desember 2020. Pengabdi menjelaskan cara mengunggah foto dan video pada story dan feed Instagram, membuat caption yang menarik, menentukan hashtag penjualan, memfollow calon konsumen, menata feed agar rapi dan terlihat menarik, dan lain sebagainya. Pengabdi juga menyarankan untuk menampilkan akun shopee di link bio Instagram agar terintegrasi dan meningkatkan penjualan. Setelah diberikan arahan dan pendampingan pemasaran digital selama 3 minggu, kini UMKM Al Barik dapat mengoperasikan sosial media sebagai media pemasaran produk dengan baik. Pengabdi berharap program kerja ini masih terus berlangsung dan bertahan karena memberikan peluang untuk meningkatkan penjualan dan memperluas pasar.

\section{Pendampingan Penjualan Online}

Pengabdi memutuskan untuk membuatkan akun Shopee sebagai media penjualan online. Terdapat beberapa keuntungan yang didapat ketika menjual produk menggunakan aplikasi marketplace ini, yaitu sifatnya gratis, semua orang bisa mengakses, pengguna shopee semakin hari semakin meningkat, dan dapat memberikan ongkos kirim secara gratis. Kegiatan pendampingan penjualan online ini dilakukan secara daring dan luring tanggal 1 Desember 2020 sampai dengan 21 Desember 2020. Setelah membuatkan akun, pengabdi memberikan arahan kepada pemilik dan karyawan cara membuat deskripsi, mengunggah foto dan video, menambahkan produk, mengikuti pengguna shopee, membalas pesan dari pengguna atau calon konsumen, dan lain sebagainya. Saat ini, pemilik dan karyawan mampu mengoperasikan aplikasi Shopee sebagai media penjualan produk secara online.

\section{Strategi Branding Produk}

Kegiatan ini dilakukan kepada seluruh anggota UMKM untuk saling berbagi ide membuat branding produk. Pengabdi memberikan arahan cara melakukan foto dan video produk agar terlihat menarik. Pengabdi juga membuatkan desain logo dan kemasan produk. Kegiatan ini dilakukan sebanyak 3 kali pertemuan pada tanggal 28 November 2020 sampai 12 Desember 2020. Hasil dari kegiatan ini adalah produk keripik ini memiliki branding yang unik dan menarik branding produk ini memberikan dampak yang nyata kepada UMKM karena kemasan yang menarik merupakan salah satu stretagi pemasaran yang penting. 
Secara ringkas, hasil yang didapatkan oleh pihak UMKM Al Barik dengan adanya kegiatan pengabdian ini adalah:

a. UMKM Al Barik memiliki visi, misi, dan tujuan yang jelas sehingga usaha yang berjalan lebih terarah.

b. UMKM Al Barik memiliki pembukuan sederhana dengan mencatat setiap transaksi keuangan yang ada.

c. UMKM Al Barik memiliki produk kemasan yang menarik dengan berbagai variasi ukuran

d. Pembaharuan akun media sosial Instagram sebagai sarana pemasaran produk.

e. Pembuatan akun bisnis pada Shopee yang dapat meningkatkan penjualan dan memperluas pasar.

Tabel 1. Capaian Kegiatan

\begin{tabular}{|c|c|}
\hline Capaian & Keterangan \\
\hline $\begin{array}{l}\text { Terciptanya Visi, Misi, } \\
\text { dan Tujuan UMKM }\end{array}$ & $\begin{array}{l}\text { Pemilik mampu } \\
\text { menyampaikan } \\
\text { keinginannya sebagai } \\
\text { pengusaha yang tertuang } \\
\text { dalam visi, misi, dan tujuan } \\
\text { UMKM. }\end{array}$ \\
\hline $\begin{array}{l}\text { Modal yang semakin } \\
\text { bertambah }\end{array}$ & $\begin{array}{l}\text { Penjualan yang semakin } \\
\text { meningkat } \\
\text { UMKM Al Barik dapat } \\
\text { bertahan }\end{array}$ \\
\hline $\begin{array}{l}\text { Meningkatnya } \\
\text { keterampilan } \\
\text { kelompok }\end{array}$ & $\begin{array}{l}\text { Kelompok usaha UMKM } \\
\text { Al Barik mampu melakukan } \\
\text { pembukuan sederhana } \\
\text { yakni mengkategorikan } \\
\text { kedalam akun, mencatat } \\
\text { transaksi penjualan, } \\
\text { menentukan harga pokok } \\
\text { penjualan, dan menyusun } \\
\text { buku besar dan membuat } \\
\text { laporan keuangan berupa } \\
\text { neraca saldo. }\end{array}$ \\
\hline $\begin{array}{l}\text { Meningkatnya } \\
\text { keterampilan } \\
\text { karyawan dalam } \\
\text { melakukan pemasaran } \\
\text { digital dan penjualan } \\
\text { online. }\end{array}$ & $\begin{array}{l}\text { Kelompok usaha mampu } \\
\text { mengoperasikan Media } \\
\text { Sosial berupa Shopee dan } \\
\text { Instagram untuk pemasaran }\end{array}$ \\
\hline $\begin{array}{l}\text { Meningkatkan } \\
\text { keterampilan } \\
\text { kelompok usaha untuk } \\
\text { membangun branding } \\
\text { suatu produk }\end{array}$ & $\begin{array}{l}\text { Pemilik dan karyawan } \\
\text { memahami makna branding } \\
\text { yaitu membangun persepsi } \\
\text { produk yang kreatif dan } \\
\text { unik terhadap konsumen }\end{array}$ \\
\hline
\end{tabular}

Tabel 1 menunjukkan capaian program yang direalisasikan selama kurang lebih 4 (empat) bulan melakukan pengabdian pada UMKM Al Barik

\section{UCAPAN TERIMA KASIH}

Kegiatan pengabdian ini tidak akan berhasil tanpa kesediaan mitra yakni pihak UMKM Al Barik. Tim pengabdi mengucapkan terima kasih atas partisipasi pihak UMKM Al Barik. Ucapan terima kasih juga tim pengabdi sampaikan kepada Fakultas Bisnis Universitas PGRI Yogyakarta yang telah memberikan dukungan untuk pelaksanaan program pengabdian ini.

\section{PENUTUP}

\section{Kesimpulan}

Kegiatan pengabdian masyarakat ini bertujuan untuk membantu menyelesaikan kendala atau permasalahan yang terjadi di UMKM Al Barik dengan memberikan solusi melalui program kerja. Pengabdi menyusun program kerja sesuai dengan kebutuhan UMKM Al Barik diantara lain sosialisasi pentingnya visi misi usaha, pemberian modal kepada pemilik, pendampingan pembukuan sederhana, pendampingan pemasaran digital, pendampingan penjualan online, dan strategi branding produk. Setelah program kerja dijalankan sesuai jadwal yang telah disusun oleh pengabdi, maka terlihat hasil yang dicapai yaitu terciptanya visi, misi, dan tujuan UMKM. Selain itu, modal pemilik juga semakin bertambah sehingga bisa diputar untuk perkembangan usaha. Kelompok usaha dapat memahami dan melakukan pembukuan sederhana untuk mencatat setiap transaksi yang ada. Kelompok usaha juga mampu mengoperasikan media sosial yaitu Instagram untuk media pemasaran dan Shopee untuk media penjualan online. Untuk bisa menunjang konten pemasaran di media sosial, pemilik dan karyawan juga memahami strategi branding produk dengan foto dan video.

\section{Saran}

Saran untuk pihak UMKM terutama untuk keberlanjutan program yang sudah ada yakni pihak UMKM Al Barik kedepan dapat melakukan pembukuan secara automatisasi untuk 
mempermudah dan mempercepat proses pembuatan laporan keuangan. Memberikan pelatihan kepada kelompok usaha dengan menggunakan Software Akuntansi dalam kegiatan pembukuannya. Serta UMKM dapat memperluas pemasaran ke market place yang lain serta ikut dalam pameran-pameran yang dilakukan oleh pemerintah daerah dalam rangka mendongkrak pengenalan produk UMKM.

\section{DAFTAR PUSTAKA}

Angelina, Y., Octaviani, A., \& Triono, B. S. (2020). Pemanfaatan Kulit Pisang dan Tanaman Herbal Sebagai Bahan Pembuatan Es Krim Yang Bernilai Ekonomi. Jurnal Pengabdian Kepada Masyarakat, 4(1), 10.

Apriyanti, M. E. (2018). Pentingnya Kemasan terhadap Penjualan Produk Perusahaan. Sosio EKons, 10(1), 20. https://doi.org/10.30998 /sosioekons.v10i1.2223

Helmalia, \& Afrinawati. (2018). Pengaruh ECommerce Terhadap Peningkatan Pendapatan Usaha Mikro Kecil Dan Menengah Di Kota Padang. JEBI (Jurnal Ekonomi Dan Bisnis Islam), 3(2), 237. https://doi.org/10.15548 /jebi.v3i2.182

Philip, Kotler (2000), Marketing Management Millenium Edition, Prentice Hall International, Inc, Kotler, Phillip \& Amstrong, Gary (1996), Principles of Marketing.Prentice Hall.Inc

Purwidiantoro, M. H., Kristanto, D. F., \& Hadi, W. (2016). Pengaruh Penggunaan Media Sosial Terhadap Usaha Kecil Menengah (UKM). AMIK Cipta Darma Surakarta, 1(1), 30-39. http://journal.amikomsolo.ac.id/index.php/ekac ida/article/view/19/11

Puspitasari, N. P. D., Ainun, D.N., Reffan B., Nandar D. C., Mustika. (2019). Penerapan Teknologi Digital Marketing Untuk Meningkatkan Strategi Pemasaran Snack Tiwul. JSAI, Volume 2 Nomor 2.

Sugiarti, E. N., Diana, N., \& Mawardi, M. C. (2019). Peran Fintech Dalam Meningkatkan Literasi Keuangan Pada Usaha Mikro Kecil Menengah Di Malang. E-Jra, 08(4), 90-104.

Utari, T., \& Dewi, P. M. (2014). Pengaruh Modal, Tingkat Pendidikan Dan Teknologi Terhadap Pendapatan Usaha Mikro Kecil Dan Menengah (UMKM) Di Kawasan Imam Bonjol Denpasar Barat. Ekonomi Pembangunan, 3(12), 576-585. 